\title{
Terapi periodontal non-bedah Non-surgical periodontal therapy
}

\author{
${ }^{1}$ Liana Zulfa, ${ }^{2}$ Dewi Nurul Mustaqimah \\ ${ }^{1}$ Peserta Pendidikan Dokter Gigi Spesialis Periodonsia \\ ${ }^{2}$ Departemen Periodonsia \\ Fakultas Kedokteran Gigi, Universitas Indonesia \\ Jakarta, Indonesia
}

\begin{abstract}
Non surgical periodontal therapy is the first step in periodontal therapy procedure. Elimination of biofilm and mineral deposit from tooth surface is a basic of periodontal therapy. Clinical data showed that the success of long term periodontal therapy depends on the result of first step compare to spesific surgical therapy. Methods used in non surgical therapy are mechanical instrumentation, ultrasonic debridement, supragingival and subgingival irigation, localized drugs, systemic antibiotics, and host response modulation. The successful of periodontal therapy depends on the management of negative environment and reduction of bacterial pathogen through a combination of better environment which is less anaerobic for good microorganism to live. The aim of non surgical therapy is to reduce microbial etiology and factors involved in the progression of gingiva and periodontal. The end result is to stop the disease progression and to gain healthy gingiva and tissue condition.
\end{abstract}

Keywords: periodontal theraphy, non surgical method, biofilm and mineral deposit

\begin{abstract}
ABSTRAK
Terapi periodontal non-bedah adalah tahap awal rangkaian prosedur perawatan periodontal. Pembuangan biofilm dan deposit mineral dari permukaan gigi merupakan dasar dan penentu dari terapi periodontal. Data klinis menunjukkan keberhasilan jangka panjang perawatan lebih bergantung pada hasil dari terapi tahap pertama dibandingkan terhadap terapi bedah spesifik. Terdapat beberapa cara perawatan non-bedah, antara lain instrumentasi mekanis, ultrasonic debridement, irigasi supragingiva dan subgingiva, pemberian obat-obatan lokal, antibiotik sistemik, dan modulasi respons inang. Keberhasilan terapi periodontal bergantung pada penataan lingkungan negatif, faktor kebiasaan dan pengurangan bakteri patogen melalui kombinasi lingkungan yang lebih baik, yaitu dengan suasana kurang anaerobik sehingga mikrobiota yang baik dapat hidup. Tujuan terapi non-bedah adalah mengurangi etiologi mikroba dan faktor-faktor yang berperan dalam perkembangan penyakit gingiva dan periodontal. Hasil akhirnya adalah berhentinya proses perkembangan penyakit serta kembalinya kondisi gingiva dan jaringan pada keadaan sehat.
\end{abstract}

Kata kunci: terapi periodontal, metode non-bedah, biofilm, deposit mineral.

Koresponden: Liana Zulfa, Peserta Program Pendidikan Dokter Gigi Spesialis Periodontologi, Departemen Periodontologi, Fakultas Kedokteran Gigi, Universitas Indonesia, Jakarta, Indonesia.

\section{PENDAHULUAN}

Terapi periodontal non-bedah adalah terapi tahap pertama dalam rangkaian prosedur yang menentukan perawatan periodontal. ${ }^{1}$ Menurut Braun $\mathrm{dkk}^{2}$ pembuangan biofilm dan deposit mineral dari permukaan gigi merupakan aspek dasar dan penentu dari terapi periodontal. Walaupun prosedur debridement dapat menurunkan penyakit periodontal yang umumnya terlihat sebagai peningkatan kedalaman poket dan keterlibatan furkasi, ternyata banyak bakteri tetap berada pada permukaan akar sehingga mempengaruhi penyembuhan setelah perawatan.

Data klinis menunjukkan bahwa keberhasilan jangka panjang perawatan periodontal lebih bergantung pada hasil yang dicapai dalam terapi tahap pertama dibandingkan terhadap terapi bedah spesifik. Terapi tahap ini memberikan kesempatan kepada dokter gigi untuk mengevaluasi respon jaringan dan perilaku pasien terhadap perawatan periodontal, karena kedua faktor ini sangat dibutuhkan untuk keberhasilan perawatan. ${ }^{1}$ Keberhasilan terapi periodontal bergantung pada penatalaksanaan lingkungan negatif dan faktor kebiasaan serta pengurangan bakteri patogen melalui kombinasi pengembalian lingkungan yang lebih baik, yaitu suasana kurang anaerobik. ${ }^{3}$

Berbagai metode perawatan, antara lain instrumentasi mekanis, ultrasonic debridement, irigasi supragingiva, irigasi subgingiva, pemberian obat-obatan secara lokal, antibiotika sistemik, dan modulasi respon inang. ${ }^{4}$ Pada artikel ini akan dijabarkan pengertian tindakan perawatan periodontal non-bedah serta metode-metode yang dapat dilakukan untuk mencapai keberhasilan perawatan periodontal. 


\section{TINJAUAN PUSTAKA}

Selain penegakan diagnosis dan penetapan macam perawatan periodontitis, juga diperlukan pemahaman mengenai patogenesis penyakit periodontal serta perawatan yang baik dan tepat. Hingga kini penggunaan probe periodontal untuk penegakan diagnosis dan pencatatan status periodontal telah rutin dilakukan. Perawatan periodontal membutuhkan diagnosis definitif karena penyakit tidak dapat dirawat secara adekuat jika tidak didiagnosis dengan tepat. ${ }^{5}$

Strategi penerapan perawatan periodontitis harus dipusatkan pada etiologinya. Pada periodontitis moderat (kedalaman poket $4-5 \mathrm{~mm}$ ) dan berat (kedalaman poket $>6 \mathrm{~mm}$ ) dapat terjadi kehilangan tulang alveolar 2-3 kali lebih besar dalam waktu 10 tahun. Data ini membuktikan bahwa penurunan kedalaman poket merupakan hal yang penting dalam perawatan periodontal. ${ }^{6}$

Tujuan dari tahap non-bedah ini adalah untuk mengurangi etiologi mikroba dan faktor-faktor yang berperan dalam perkembangan penyakit gingiva dan periodontal. Hasil akhirnya adalah menghentikan proses perkembangan penyakit serta mengembalikan kondisi gingiva dan jaringan periodontal pada keadaan sehat dan nyaman. Tahap terapi ini dapat juga disebut sebagai terapi inisial, nonsurgical periodontal therapy, causerelated therapy, dan etiotropic phase of therapy. ${ }^{1}$

Prosedur yang termasuk dalam terapi ini dapat merupakan terapi satu-satunya. Namun jika terapi ini tidak dapat mengatasi masalah pasien, harus dilakukan tahap persiapan untuk terapi bedah. ${ }^{1}$ Tujuan utama dari perawatan periodontal non-bedah adalah untuk menekan dan mencegah flora patogen mikrobial subgingiva berkembang kembali sehingga lesi inflamasi dapat berkurang. ${ }^{7}$

\section{Instrumentasi mekanis}

Instrumentasi mekanis terhadap akar dengan menggunakan kuret merupakan perawatan yang efektif pada pasien dengan periodontitis ringan sampai berat, yaitu dengan kerusakan perlekatan jaringan klinis kurang dari $5 \mathrm{~mm}$. Beberapa penelitian telah mengungkapkan bahwa penghalusan akar dapat mengurangi kedalaman poket, meningkatkan perlekatan klinis jaringan dan menghambat progresivitas penyakit. Peningkatan perlekatan klinis jaringan mengarah pada perlekatan jaringan ikat baru, yaitu serat periodontal baru yang ada di dalam sementum, atau pembentukan long junctional epithelium. ${ }^{4}$

Modalitas perawatan tradisional skeling dan penghalusan akar tetap merupakan "standar emas" untuk penanganan periodontitis secara nonbedahdap. $^{7}$ Bukti klinis memperlihatkan rerata penurunan kedalaman poket dan peningkatan perlekatan klinis dapat dicapai dengan penghalusan akar pada daerah dengan kedalaman poket $4-6 \mathrm{~mm}$ atau $7 \mathrm{~mm}$ lebih. Rata-rata penurunan kedalaman poket adalah $1,29 \mathrm{~mm}$ dan $2,16 \mathrm{~mm}$, dan rata-rata peningkatan perlekatan klinis adalah $0,55 \mathrm{~mm}$ dan $1,29 \mathrm{~mm}$. Penurunan kedalaman poket biasanya lebih besar pada daerah dengan kedalaman probing awalnya lebih besar. ${ }^{4}$

Penelitian-penelitian sebelumnya yang dikutip oleh Perry dkk, mengindikasikan bahwa skeling dan penghalusan akar sangat efektif dalam penanganan penyakit periodontal. Penelitian dalam jangka waktu 1 bulan hingga 2 tahun menunjukan adanya pengurangan perdarahan saat probing hingga $80 \%$ dan penurunan kedalaman poket mulai $2 \mathrm{~mm}$ hingga $3 \mathrm{~mm}$. ${ }^{1}$

Menurut Cobb, ${ }^{7}$ terdapat tiga hal yang harus dipertimbangkan dalam pengambilan keputusan perawatan non-bedah sebagai perawatan utama periodontitis kronis ringan dan moderat, yaitu klinisi harus cermat menginterpretasi data pasien, serta mampu memperkirakan waktu yang dibutuhkan untuk melakukan perawatan, tingkat kemampuan, tingkat keparahan penyakit, maupun banyaknya jumlah pasien. Selain itu harus diingat bahwa mikroba yang ada pada biofilm subgingiva yang matur dan tidak tersentuh dapat menyebabkan peningkatan toleransi terhadap agen antimikroba. Yang terakhir, walaupun periodontitis kronis telah berhasil dirawat, penurunan mikroba patogen subgingiva hanya bersifat sementara. Skeling dan penghalusan permukaan akar dapat membuka tubuli dentin dan menyebabkan invasi patogen periodontal sehingga banyak bakteri akan kembali menginfeksi poket. Dibutuhkan perawatan selanjutnya yang terdiri dari debridement supragingiva dan subgingiva dengan interval 3-4 bulan untuk mempertahankan efek yang sudah didapatkan sebelumnya.

Sebelum memilih metode perawatan, klinisi harus mempertimbangkan keparahan kondisi periodontal. Dokter gigi juga harus memperkirakan hasil perawatan dan mengevaluasi kemampuan instrumentasi mekanis. Secara umum instrumentasi mekanis telah berhasil menstabilkan tingkat perlekatan klinis pada pasien periodontitis ringan sampai moderat. Jika hasil yang diharapkan ialah penambahan tulang dan penurunan kedalaman poket dalam skala yang besar, maka dibutuhkan prosedur bedah. ${ }^{4}$ Kontrol peradangan dan penurunan kedalaman poket secara mekanis 
perlu dilengkapi dengan penggunaan antimikroba, sampling plak dan uji sensitivitas antibiotik. ${ }^{1}$

\section{Ultrasonic debridement}

Istilah ultrasonic debridement mengarah pada pembersihan permukaan akar dengan alat mekanis vibrasi. Prosedur ini berbeda dengan tindakan penghalusan akar, tetapi menurut beberapa penelitian didapatkan hasil yang hampir sama dengan skeling dan penghalusan akar terhadap penurunan kedalaman poket, peningkatan perlekatan klinis dan penurunan inflamasi klinis. ${ }^{4}$

Renvert dkk, ${ }^{8}$ membandingkan dua metode pembersihan mekanis pada peri-implanitis, yaitu menggunakan kuret titanium kemudian dipoles dengan rubbercup dan pasta poles, serta alat ultrasonik dengan tip khusus untuk perawatan infeksi sekitar implan kemudian dipoles dengan rubbercup dan pasta poles. Perbandingan analisis data antara saat awal dengan bulan ke-6 pada kedua metode pembersihan memperlihatkan peningkatan bermakna kebersihan mulut, yaitu rata-rata plak indeks (PI) 73\% menjadi 53\%. Pada bulan ke-6 indeks perdarahan juga mengalami penurunan secara bermakna.

Penelitian Greenstein $\mathrm{dkk}^{4}$ memperlihatkan bahwa pada daerah dengan kedalaman poket lebih dari $4 \mathrm{~mm}$, terjadi penurunan rata-rata kedalaman poket antara 1,2-2,3 $\mathrm{mm}$ setelah penghalusan akar dan 1,7-1,9 mm setelah ultrasonic debridement. Ultrasonic debridement tidak menyebabkan overinstrumentasi pada akar sehingga tidak menyebabkan dentin hipersensitif. Ultrasonic debridement mengurangi waktu kerja dan kelelahan pada operator dibandingkan terhadap instrumentasi manual. Tetapi sebaliknya penghalusan akar menghasilkan permukaan akar yang lebih halus secara mikroskopis dibandingkan ultrasonic debridement, walaupun perbedaan tersebut tidak terlihat secara klinis.

Akses yang adekuat untuk debridement subgingiva akan lebih sulit pada kedalaman poket yang lebih dalam. Sat ini telah dikembangkan berbagai alat ultrasonik untuk meningkatkan debridement permukaan akar subgingiva berupa alat yang lebih tipis dan atau dengan tangkai yang lebih panjang. ${ }^{9}$

Instrumentasi ultrasonik menyebabkan terjadinya aerosol yang mengandung darah dan bakteri. Aerosol dapat terjadi dalam jarak beberapa meter dari operator dan dapat berada di udara selama 30 menit. Klinisi harus memakai masker dan suction kecepatan tinggi, serta pasien diminta untuk menggunakan obat kumur sebelum tindakan untuk mengurangi jumlah bakteri dalam saliva. Penggunaan alat ultrasonik atau tip mikroultrasonik (lebar $<0,5 \mathrm{~mm}$ ) sama efektifnya dengan skeling dan penghalusan akar. Dapat juga diberikan tambahan perawatan berupa irigasi obatobatan pada poket yang dalam. ${ }^{4}$

\section{Irigasi supragingiva}

Pada awal tahun 1980, terdapat keraguan apakah irigasi supragingiva dapat memberikan keuntungan yang lebih dibandingkan dengan penyikatan gigi pada kontrol plak dan gingivitis. Sejak itu dilakukan penelitian yang menyatakan irigasi supragingiva dapat meningkatkan efek penyikatan gigi dan mengurangi inflamasi gingiva pada pasien dengan kebersihan mulut tidak baik. Penurunan inflamasi gingiva berkisar antara 6,5$54 \%$. Hal ini terjadi akibat penurunan jumlah plak supragingiva dan penetrasi irigan subgingiva sekunder yang membasuh bakteri keluar dari poket. Berbagai penelitian menunjukkan kemampuan irigasi supragingiva. Hal ini terbukti melalui irigasi supragingiva dengan tip irigasi standar mampu menghantarkan air atau obatobatan sedalam $3 \mathrm{~mm}$ subgingiva atau mendekati setengah dari kedalaman poket $6 \mathrm{~mm}$ (gambar 1A,C). Alat lain, yaitu pik pocket (Teledyne) jika ditempatkan $1 \mathrm{~mm}$ subgingiva dapat memfasilitasi penetrasi irigan sampai $90 \%$ pada poket $6 \mathrm{~mm}^{4}$
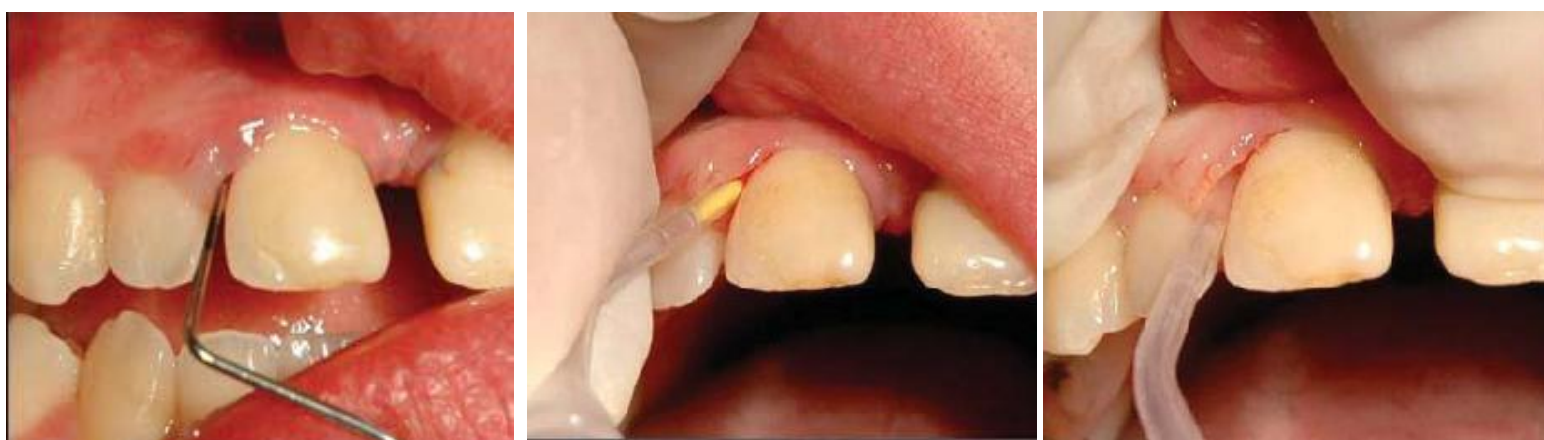

Gambar 1. A. Kedalaman poket $6 \mathrm{~mm}$ sebelum perawatan. B. Insersi awal pemberian minosiklin mikrosfer.

C. Penempatan tip pada dasar poket 
Beberapa penelitian pada awal tahun 1990 juga menyatakan bahwa kontrol plak supragingiva yang baik dapat mengurangi populasi bakteri di dalam poket sampai kedalaman $5 \mathrm{~mm}$. Penelitian tersebut membuktikan bahwa irigasi supragingiva bermanfaat terhadap kontrol plak supragingiva dan subgingiva dan mengurangi inflamasi gingiva sehingga dapat berperan sebagai alat bantu tambahan dalam meningkatkan kebersihan mulut. Meskipun demikian harus diingat bahwa irigasi subgingiva tidak meningkatkan hasil yang dicapai oleh skeling dan penghalusan akar. Terdapat satu penelitian yang mengemukakan bahwa irigasi selama 5 menit setiap gigi dengan tetrasiklin konsentrasi $10 \%$ jika digunakan bersamaan dengan penghalusan akar dapat meningkatkan perlekatan klinis dibandingkan dengan perlakuan penghalusan akar saja, yaitu 1,8 $\mathrm{mm}$ berbanding 1 mm. ${ }^{4}$

\section{Pemberian obat-obatan secara lokal}

Penggunaan doxycycline hyclate $10 \%$, gel metronidazole $25 \%$, dan serat tetrasiklin impegrated terbukti memperlihatkan hasil yang sama dengan perlakuan penghalusan akar, dengan penurunan kedalaman poket $(1 \mathrm{~mm})$ dan peningkatan perlekatan klinis. Jika dilakukan penghalusan akar saja dibandingkan dengan penghalusan akar dan penempatan perio chip, dapat terjadi perbedaan kedalaman poket sebesar 2 $\mathrm{mm}$. Hasil yang baik ini terutama didapatkan dengan terapi kombinasi. Untuk mencapai hal ini peneliti menempatkan chip dua atau tiga kali pada $60 \%$ lokasi selama 9 bulan periode evaluasi. ${ }^{4}$

Beberapa pendekatan kemoterapeutik tambahan telah dikembangkan, diuji dan terbukti berhasil pada pasien periodontitis kronis. Antimikroba yang diberikan secara lokal setelah perawatan mekanis sebagai kombinasi skeling dan penghalusan akar dapat meningkatkan efektivitas perawatan periodontal. Hal ini memudahkan antimikroba atau antibiotik dengan obat polimer melepaskan obat ke dalam poket. ${ }^{6}$

Prosedur tambahan yang diberikan yaitu pemberian antibiotika secara lokal dan sistemik, atau penempatan subgingival chip klorheksidin telah diteliti. Di antara antimikroba tambahan yang diberikan secara lokal, yang memberikan hasil paling efektif adalah tetrasiklin, minosiklin (gambar 1B), metronidazole, dan klorheksidin. ${ }^{2}$

Pemberian obat-obatan secara lokal tidak efektif terhadap organisme invasif jaringan seperti A. actinomycetemcomitans. Dengan demikian klinisi harus mempertimbangkan pasien yang bukanlah merupakan metode terbaik dalam membuang biofilm, agregat bakteri, sehingga tidak dapat digunakan sebagai pengganti penyikatan gigi atau perawatan pemeliharaan secara berkala. ${ }^{4}$

\section{Irigasi subgingiva}

Beberapa penelitian menemukan bahwa irigasi subgingiva dengan berbagai macam obatobatan mampu mengurangi jumlah bakteri patogen subgingiva. Akan tetapi satu kali irigasi tidak merespons baik obat-obatan lokal ini untuk diberikan obat-obatan secara sistemik. ${ }^{4}$ Menurut Sweeting dkk, ${ }^{5}$ lokasi yang dapat diberikan obatobatan secara lokal antara lain poket > $5 \mathrm{~mm}$ dengan perdarahan gingival, setelah skeling dan penghalusan akar awal, poket $>5 \mathrm{~mm}$ dengan perdarahan gingiva atau lokasi $>6 \mathrm{~mm}$, lokasi yang direncanakan untuk pemberian cangkokan tulang, abses periodontal, kedalaman poket pada distal-fasial line angle dari molar kedua yang berhubungan dengan pencabutan gigi molar ketiga jika tindakan intervensi bedah menghasilkan kondisi kompromis, peri-implanitis yang bukan indikasi tindakan bedah, serta keterlibatan furkasi kelas II (dangkal atau dalam) yang tidak akan dilakukan tindakan bedah.

Dokter gigi harus mengestimasi jumlah waktu kunjungan yang dibutuhkan berdasarkan keadaan pasien. Salah satu contoh yang dapat dilakukan adalah menjadwalkan sebuah kunjungan yang lama atau dua kunjungan singkat sementara pasien menerima agen antimikrobial, lalu jadwalkan kunjungan berikutnya selama masa penyembuhan. Rangkaian perawatan ini disebut juga perawatan anti-infeksi atau disinfeksi. Data dari penelitian sebelumnya menunjukan adanya perbaikan pada kedalaman poket dan pengurangan periodontal patogen pada kelompok yang memakai agen antimikroba. ${ }^{1}$

\section{Antibiotik sistemik}

Terapi antibiotika sistemik memberikan keuntungan lebih banyak dibandingkan dengan yang diberikan secara lokal. Antibiotika sistemik dapat diberikan melalui serum ke dasar poket dan mempengaruhi organisme invasif jaringan seperti A.actinomycetemcomitans. Selain itu juga dapat mempengaruhi sumber dari reinfeksi bakteri, yaitu saliva, tonsil, dan mukosa. Obat sistemik ini juga lebih murah biayanya dan mempersingkat waktu perawatan pasien. ${ }^{4}$

Jika pemeriksaaan mikrobiologis menunjukkan adanya $A$. actinomycetemcomitans maka disarankan penggunaan kombinasi obat 
amoksisilin dengan asam klavulanat dan metronidazol, yang merupakan antibiotik spesifik untuk obligat anaerob. Jika pasien alergi terhadap penisilin, dapat diberikan siprofloksasin sebagai pengganti amoksisilin dengan asam klavulanat. Siprofloksasin efektif terhadap stafilokokus, pseudomonas, dan enteric rods. Selain itu dapat juga digunakan klindamisin. ${ }^{4}$

Belakangan ini mulai digunakan Azitromisin yang efektif terhadap anaerob dan basil negatif gram. Setelah pemberian $500 \mathrm{mg}$ satu kali sehari selama 3 hari, kadar azitromisin masih dapat dideteksi pada jaringan selama 7-10 hari. Azitromisin berpenetrasi ke dalam fibroblas dan fagosit 100-200 kali lebih besar dan diedarkan ke daerah inflamasi oleh fagosit kemudian dilepaskan pada proses fagositosis. ${ }^{1}$

Haas $\mathrm{dkk}^{10}$ pada penelitiannya mengemukakan bahwa penggunaan azitromisin berpotensi meningkatkan kesehatan jaringan periodontal pada pasien periodontitis agresif. Pemeriksaan tersebut dilakukan pada bulan ke-3, ke-6, ke-9, dan ke-12 terhadap kedalaman poket dan peningkatan perlekatan klinis.

\section{Modulasi respons inang}

Terdapat pendekatan untuk meningkatkan perawatan konvensional dari periodontitis termasuk pemberian obat modulasi respons inang untuk menghambat aspek destruktif dari respon imun. Food and Drug Administration (FDA) telah menyetujui penggunaan obat-obat sistemik sebagai tambahan skeling dan penghalusan akar. Periostat merupakan inhibitor kolagenase yang terdiri dari $20 \mathrm{mg}$ doxycycline hyclate untuk pemberian secara oral. Walaupun periostat merupakan antibiotika, tetapi diberikan dalam dosis yang rendah sehingga tidak terjadi aktivitas bakteri. ${ }^{4}$

Rata-rata peningkatan perlekatan klinis dengan kedalaman poket awal 4-6 mm adalah 1,03 $\mathrm{mm}$ setelah penghalusan akar dan pemberian dosis subantibakteri doksisiklin (SDD) dan $0,86 \mathrm{~mm}$ setelah penghalusan akar saja, terdapat perbedaan sebesar 0,17 mm. Pada daerah dengan kedalaman probing awal $7 \mathrm{~mm}$ atau lebih, rata-rata peningkatan perlekatan klinis adalah $1,55 \mathrm{~mm}$ pada penghalusan akar dan SDD, dan $1,17 \mathrm{~mm}$ pada penghalusan akar saja; terdapat perbedaan sebesar $0,38 \mathrm{~mm}^{4}$

Pada daerah dengan kedalaman poket awal 4$6 \mathrm{~mm}$, rata-rata penurunan kedalaman poket adalah $0,95 \mathrm{~mm}$ setelah penghalusan akar dan $\mathrm{SDD}$, dan 0,69 $\mathrm{mm}$ setelah penghalusan akar saja; berbeda $0,26 \mathrm{~mm}$. Pada daerah dengan kedalaman poket awal $7 \mathrm{~mm}$ atau lebih, rata-rata penurunan kedalaman poket adalah 1,68 $\mathrm{mm}$ setelah penghalusan akar dan SDD, dan 1,20 mm setelah penghalusan akar saja; terdapat perbedaan $0,48 \mathrm{~mm}$. Para klinisi harus berusaha mengeliminasi bakteri menggunakan terapi konvensional sebelum menggunakan obat sistemik yang mampu mengubah respons inang terhadap patogen. ${ }^{4}$

\section{Aplikasi laser}

Belakangan ini, penggunaan laser mulai diminati dalam perawatan poket periodontal, seperti ablasi dan detoksifikasi. Penggunaan laser ini juga disarankan sebagai instrumentasi mekanis konvensional tambahan. Untuk pembuangan kalkulus subgingiva dapat digunakan laser Er:YAG karena tidak menyebabkan perubahan suhu pada permukaan akar. Er:YAG menggunakan pendingin air yang efektif tanpa mengurangi efektivitasnya. Beberapa penelitian pada binatang menunjukkan secara histologis tidak ada efek merugikan terhadap jaringan pulpa akar setelah debridement dengan laser Er:YAG. ${ }^{11}$

Penelusuran kepustakaan Sicilia $\mathrm{dkk}^{12}$ menunjukkan metode lain dalam perawatan tahap awal, yaitu aplikasi laser diode (LD) dalam perawatan hipersensitivitas dentin. Iradiasi pada gigi dapat dengan kekuatan rendah ( $\mathrm{He}-\mathrm{Ne}$, diode) dan menengah (CO2, Nd:YAG). Kekuatan yang rendah terbukti memiliki efek antiinflamasi yang signifikan. Sedangkan kekuatan menengah memiliki efek berlebih terhadap pulpa. Laser diode (gallium/aluminium/arsenide-GaAlAs) mampu menghasilkan gelombang yang berkesinambungan tanpa overheating (rentang panjang gelombang 660-900 nm) dengan lama aplikasi 60-150 detik setiap gigi pada setiap pasien. Iradiasi LD mampu mengurangi hipersensitivitas dentin, sama seperti penggunaan potasium nitrat, sodium fluoride, stannous fluoride, dan fluoride varnish.

Berdasarkan penelitian Sicilia dkk., penggunaan LD pada panjang gelombang $<780$ nm dan kekuatan di bawah $30 \mathrm{~mW}$ dengan waktu aplikasi < 3 menit dapat menghasilkan perawatan yang aman terhadap pulpa. Penggunaan laser yang tidak tepat dapat berpotensi merusak jaringan, lesi termal pada permukaan radikular, jaringan gingiva, pulpa, dan tulang. Perawatan dengan LD yang tepat dapat menutup tubuli dentin sama halnya dengan efek analgesia terhadap pulpa. ${ }^{12}$ 


\section{PEMBAHASAN}

Pembuangan biofilm dan deposit mineral dari permukaan gigi merupakan aspek dasar perawatan. $^{2}$ Debridement permukaan akar merupakan komponen vital dari perawatan bedah dan non-bedah. ${ }^{9}$

Modalitas perawatan tradisional dari skeling dan penghalusan akar tetap merupakan "standar emas" untuk penanganan non-bedah terhadap periodontitis. ${ }^{7}$ Telah digunakan juga laser dalam kedokteran gigi modern selama lebih dari 30 tahun. Penggunaan luas dari laser, seperti $\mathrm{CO}$, Nd:YAG, dan Er:YAG dalam bidang periodontologi untuk ablasi jaringan lunak dan keras, detoksifikasi permukaan akar, debridement poket, eliminasi bakteri dan berbagai pendekatan bedah. ${ }^{13}$ Selain itu terdapat beberapa tulisan mengenai efisiensi perawatan non-bedah pada infeksi sekitar implan. ${ }^{8}$

Dalam perawatan periodontal, irigasi supragingiva maupun subgingiva digunakan untuk membasuh bakteri yang berkontak dengan periodontal. Tindakan ini dapat menurunkan jumlah bakteri plak. Begitu juga dengan modulasi inang, dengan menekan aktivitas kolagenase yang diproduksi oleh polimorfonuklear leukosit. ${ }^{1}$

Pada umumnya pasien dengan periodontitis kronis ringan sampai moderat member respon yang baik terhadap perawatan non-bedah, walaupun terkadang dibutuhkan juga perawatan bedah. Oleh karena itu rencana perawatan harus disesuaikan dengan tingkat keparahan penyakit pasien.

\section{SIMPULAN}

Pada pasien periodontitis kronis, perawatan konvensional berupa irigasi supragingiva dan subgingiva memberikan hasil yang baik terhadap penurunan kedalaman poket dan peningkatan perlekatan klinis. Penggunaan obat-obatan yang diberikan secara lokal dapat meningkatkan hasil perawatan, dan penggunaan antibiotik hanya diberikan pada pasien yang tidak merespon baik terhadap perawatan konvensional. Selain itu, host modulating agent juga dapat memberikan keuntungan pada pasien walaupun sebelum penggunaannya sebaiknya jumlah bakteri terlebih dahulu dikurangi.

\section{DAFTAR PUSTAKA}

1. Perry DA, Schmid MO, Takei HH. Phase I periodontal therapy.In:Newman MG, Takei H, Klokkevold PR, Carranza FA, editor. Carranza's clinical periodontology. $10^{\text {th }}$ ed. Philadelphia: W.B. Saunders;2006.p.722-880.

2. Braun A, Dehn C, Krause F, Jepsen S. Short-term clinical effects of adjunctive antimicrobial photodynamic therapy in periodontal treatment: a randomized clinical trial. J Clin Periodontol 2008; 35: 877-84.

3. Quirynen M, Teughels W, De Soete M, Van Steenberghe D. Topical antiseptic and antibiotic in initial therapy adult chronic periodontitis: microbiological aspect. Periodontol 2000 2002; 28:72-90.

4. Greenstain G. Nonsurgical periodontal therapy in 2000: a literature review. J Am Dent Assoc 2000; 131: $1580-92$.

5. Sweeting LA, Davis K, Cobb CM. Periodontal treatment protocol (PTP) for the general dental practice. J Dent Hyg 2008; 83:16-25.

6. Paquette DW, Ryan ME, Wilder RS. Locally delivered antimicrobials: clinical evidence and relevance. J Dent Hyg 2008; 83:10-5.

7. Cobb CM. Microbes, inflamation, scaling and root planing, and the periodontal condition. J Dent Hyg 2008; 83:4-9.

8. Renvert S, Samuelssen E, Lindahl C, Persson GR. Mechanical non-surgical treatment of periimplantitis: a double-blind randomized longitudinal clinical studi. i: clinical results. J Clin Periodontol 2009; 36:604-9.

9. Barendregt DS, van der Velden U, Timmerman MF, van der Weijden F. Penetration depth with an ultrasonic mini insert compared with a conventional currete in patients with periodontitis and in periodontal maintenance. J Clin Periodontol 2008;35:31-6

10. Haas AN, de Castro GD. Moreno T. Azithromycin as an adjunctive treatment of aggressive periodontitis: 12-months randomized clinical trial. J Clin Periodontol 2008; 35:696-704.

11. Ishikawa I, Aoki A, Takasaki AA, Mizutani K, Sasaki KM, Izumi Y. Application of laser in periodontics: true innovation or myth? Periodontol 2000 2009; 50:90-126.

12. Sicilia A, Cuesta-Frechoso S, Suarez A, Angulo J, Pordomingo A, De Juan P. Immediate efficacy of diode laser application in the treatment of dentine hypersensitivity in periodontal maintenance patients: A randomized clinical trial. J Clin Periodontol 2009; 36:650-60.

13. Ozcelik O, Haytac MC, Kunin A, Seydaoglu G. Improved wound healing by low-level laser irradiation after gingivectomy operations: a controlled clinical pilot studi. J Clin Periodontol 2008; 35:250-4. 

